\title{
Jelinek in Chinese: a Controversial Austrian Nobel Laureate in the Chinese Book Market
}

\author{
Arnhilt Johanna Hoefle
}

\begin{abstract}
The awarding of the world's best known literature prize to the controversial Austrian writer Elfriede Jelinek in 2004 triggered off worldwide hype in its reception. So far, Jelinek's works have been translated into more than 40 languages. Chinese is one of them. Although the author's first works had already been translated back in the 1990s, on the Chinese mainland all translations of her works were actually published only after the key event of the Nobel Prize. They immediately received immense attention from the Chinese public and unleashed what could even be termed a 'Jelinek fever'. This paper is devoted to shedding light on the first introduction and the unexpected success of this controversial Austrian Nobel laureate in the Chinese book market. It will give an overview of the Chinese translations of Jelinek's works and will try to reveal some of the dynamics that led to their actual selection, translation, publication, marketing and status as bestsellers. The challenges of the rapidly transforming Chinese publishing industry and the impact of these challenges on the reception of foreign literature will be discussed. Furthermore, the paper will outline the crucial role of the intermediaries, especially of the powerful literary agency involved, in this process of cultural transfer.
\end{abstract}

Keywords: Chinese book market, Elfriede Jelinek, literary translation, Nobel Prize

Hoefle, Arnhilt Johanna. "Jelinek in Chinese: a Controversial Austrian Nobel Laureate in the Chinese Book Market." In Vienna Graduate Journal of East Asian Studies, Volume 2, eds. Rudiger Frank, Ingrid Getreuer-Kargl, Lukas Pokorny and Agnes Schick-Chen. Vienna: Praesens Verlag, 2011, pp. 1-25.

https://doi.org/10.2478/vjeas-2011-0007 


\section{A Nobel Prize and its consequences}

On 7 October 2004, the Swedish Academy finally put an end to the annually recurring guessing game and announced the laureate of the Nobel Prize in Literature of the year 2004: the controversial Austrian writer Elfriede Jelinek, for her 'musical flow of voices and counter-voices in novels and plays that with extraordinary linguistic zeal reveal the absurdity of society's clichés and their subjugating power' (Nobelprize.org 2004). The awarding of the world's best known literature prize triggered off worldwide hype in its reception. Some publishing houses could rely on already existing editions of translations, which they started to reprint in huge numbers. Others, however, had to join in the fierce competition for the copyrights to publish the now precious Nobel works for the first time. By May 2011, Elfriede Jelinek's works had been translated into more than 40 languages (Elfriede JelinekForschungszentrum 2011). Chinese is one of them.

Although the first works by Jelinek had already been translated back in the 1990s, on the Chinese mainland all translations of her works were actually published only after the key event of the Nobel Prize. ${ }^{1}$ They immediately received immense attention from the Chinese public and unleashed what could even be termed a 'Jelinek fever'. This paper is devoted to shedding light on the first introduction and actual fortunes of this controversial Austrian Nobel laureate in the contemporary Chinese book market. By referring to textual sources, such as the Chinese discourse in the form of journalistic and academic contributions, quantitative data, such as statistics for the Chinese book market, and qualitative data, such as interviews with experts from the publishing industry, Chinese scholars of German studies, the translators and literary agents, it has been possible to reconstruct the actual course of events for the first time.

In line with studies of cultural transfer, the very complex and dynamic process of circulation and transfer becomes the centre of interest in this paper. ${ }^{2}$ It will therefore not concern itself with judging the quality or equivalence of the translations, which traditional approaches to reception are often prone to focus on exclusively. Rather, the mechanisms of selection and decision-making instead deserve closer scrutiny (Espagne and Werner 1985). Furthermore, the agents involved, especially intermediaries, and their vital role in the transfer process have to be identified.

This paper will therefore give, first of all, an overview of the challenges the Chinese book market poses to translations of foreign literary works. It will outline the recent developments of a rapidly changing industry. Next, the key facts of the translation history and the works selected within Jelinek's oeuvre will be introduced. The

1 There are translations of Jelinek's works in Taiwan too, but due to shortage of space this paper has to focus on mainland China only. 'China' hereafter is therefore deemed to mean mainland China only.

2 For a concise introduction to the studies of cultural transfer, see Keller 2011. 
paper will then focus on the crucial role of the intermediaries involved in the introduction of Jelinek's works into Chinese, which are the literary agency, the publishers and translators. Finally, the varying layouts of the Chinese editions will be analysed in order to reveal the publishers' strategies for selling Jelinek in Chinese. The success of their strategies will then be discussed in more detail, as well as the overall performance of Jelinek's works in the Chinese book market. The paper will conclude with final remarks and a tentative outlook on the reception of Jelinek and the current status of research.

\section{Challenges of the Chinese book market}

The Chinese book market is characterised by certain particularities, which are closely linked with the very specific socio-political history of the country. Before analysing the introduction of Jelinek's works, it is therefore necessary to explain briefly some of the most recent developments regarding the Chinese publishing industry, Chinese reader behaviour and the role of literature as well as literary translations in the Chinese book market.

In recent years, the Chinese book market has experienced unprecedented growth, hand in hand with China's overall economic growth in the past decades. It is now one of the largest book markets in the world and a leading force in global publishing. It is, however, still one of the industries in China where governmental control is heaviest (Bartz 2009: 1). The General Administration of Press and Publication (GAPP) 中华人民共和国新闻出版总署 (Zhōnghuá Rénmín Gònghéguó xīnwén chübăn zŏngshŭ) is the administrative agency responsible for regulating the publishing industry in China. Apart from enacting regulations, its main responsibilities include the approval of new publishing houses and the issuing of ISBNs. ${ }^{3}$

Since the implementation of the policies of reform and opening up to the outside world from 1978 onwards, and especially since China joined the World Trade Organization in 2001, the Chinese publishing industry has been undergoing major structural transformations (Sun, Yang, and Mao 2009: 93). From 2003 on, step-bystep reforms were introduced that forced the publishing industry to face the challenge of a free-market economy. The state has hence steadily withdrawn from the industry, while publishing houses, formerly entirely state-owned, non-profit organisations, are required to transform into business enterprises. The growing pressure on Chinese publishing houses becomes increasingly evident in their choice of titles and marketing strategies, as we will see in the case of Elfriede Jelinek in more detail below.

3 The International Standard Book Number (ISBN) is a unique number that identifies books and book-like products published internationally. 
In the course of China's transition over the past decades, the consumer behaviour of Chinese readers has undergone significant changes. With an increase in living standards and leisure time, book purchasing power is growing rapidly. Contrary to the traditional Chinese concept of the book as intellectually respectable and durable goods, it has now become a form of popular entertainment and an ordinary consumer product (Sun 2002: 56). Since it is highly dependent on fashion trends, its life-span has become significantly shorter. Recent surveys show that books are purchased to satisfy entertainment and relaxation needs mainly (Sun 2002: 56, Bartz 2009: 11). At the same time, books are being challenged by alternative forms of media entertainment, especially electronical forms, such as computer games, internet and mobile phones (China Publishing Today 2009b). This tendency has to be considered as well when analysing the fate of literary works in this challenging market.

Within the contemporary Chinese book market, literature is definitely a key product. It is, nevertheless, competing against a range of other very successful genres. In recent years, the top three genres have proved to be social science books, textbooks, and science and technology books, both in terms of sales revenue ratio and title ratio (China Publishing Today 2009a). They have been followed by literature and children's books.

The genre of literature is usually divided into the following eight segments: novels 小说 (xiăoshuō), essays 散杂文 (sănzáwén), children's literature 青春文学 (qīngchūn wénxué), classical Chinese literature 中国古典文学 (Zhōngguó gǔdiăn wénxué), literary theory and research 文学理论与研究 (wénxué lìlùn yǔ yánjiū), other literature 文学其他 (wénxué qitā), illustrated books and cartoons 绘本漫画 (huiběn mànhuà), as well as drama and poetry 戏剧诗歌 (xìjù shìgē) (Yáng 2006: 12 ). The novel clearly dominates the national literary market. According to an analysis by the private organisation Běijīng OpenBook IT Co. Ltd. 北京开卷信息技术有 限公司 (Béijīng Käijuàn xìnxī jìshù yǒuxiàn gōngsī), it accounted for 46 percent of the total price of books (码洋 măyáng) within the genre of literature in 2005 (Yáng 2006: 1-2). Essays and children's literature occupied approximately 16 percent each, classical Chinese literature 10 percent, literary theory and research 5 percent, other literature 3 percent, and the two segments, illustrated books and cartoons as well as drama and poetry, merely 2 percent each.

As the focus of this paper lies in the reception of translated literary works, the role of translations in the Chinese book market is of major interest. In recent years, translations in all segments have clearly gained in influence in that market. From July 2008 to June 2009, translated books accounted for approximately 20 percent of China's overall book market by title output and 30 percent of sales (China Publishing Today 2009b). In the same period under review, 96 percent of China's official publishers (556 out of the 579 by then) were involved in the market for translated books. Apart from children's books, literature is among the largest sectors of translated books and assumed more than 20 percent by value in the period 2008-2009. 
Other strong sectors include language study guides, economics and management books, academic and cultural titles and self-help books.

Approximately 10 percent of all literary titles are translations of foreign books. Most of them are titles from the United States, though a significant number of works originated in Taiwan, Hong Kong and other Asian regions. The importance of English-speaking regions as well as of other Chinese-speaking and Asian regions is also reflected in the general trade of copyrights: the US, United Kingdom, Taiwan, Hong Kong, Singapore and Macao, as well as Japan and Korea, are China's most important trading partners in this respect (Bartz 2009: 3-4).

\section{Jelinek's works in Chinese translation}

After the announcement of the Nobel Prize laureate in autumn 2004, China was struck by what could be rightly termed a 'Jelinek fever'. Within one year of being awarded the Nobel Literature Prize, 12 editions of Elfriede Jelinek's works in translation were released on to the Chinese book market. Her novel Women as Lovers (Die Liebhaberinnen) was published as part of a series again in 2008; the novel The Piano Teacher (Die Klavierspielerin) was re-published in $2010 .{ }^{4}$ In sum, eight novels and 18 dramatic texts of Elfriede Jelinek were translated into Chinese. Jelinek's novels in Chinese translation include:

À, huāngyě 啊, 荒野 (Oh wilderness, oh protection from it), 2005

Gāngqín jiàoshī 钢琴教师 (The Piano Teacher), 2005, 2010

Měihăo de měihăo de shíguāng 美好的美好的时光 (Wonderful, Wonderful Times), 2005

Mǐxià 'ài’ěr - Yĩ bù xiěgěi yòuzhì shèhuì de qīngnián dúwù 米夏埃尔 - 一部写给幼稚社会的青 年读物 (Michael. A juvenile book for the infantile society), 2005

Qíngyù 情欲 (Lust), 2005

Tānlán 贪婪 (Greed), 2005

Wǒmen shì yòuniăo, băobèi 我们是诱鸟, 宝贝 (We are decoys, baby!), 2005

Zhú ài de nürén 逐爱的女人 (Women as Lovers), 2005, 2008

4 Where Jelinek's work has been published in English translation, I will refer to this English title in the text, and follow this with the original German title for the first citation of each work. Otherwise, titles that have not been published in English translation will be cited in the original German, followed by my English translation for the first citation of each work. The Chinese titles will also be translated into English. 
Jelinek's dramatic texts in Chinese translation include:

Húnduàn Ā'érbēisī shān 魂断阿尔卑斯山 (In the Alps), 2005

Contents: “Húnduàn Ā'ěrbēisī shān” 魂断阿尔卑斯山 (In the Alps)

“Zàijiàn” 再见 (The farewell)

“Chénmò” 沉默 (The silence)

"Nŭmówáng” 女魔王 (The erlqueen)

“Mànyóuzhě” 漫游者 (The wanderer)

“Yúntuán・jiāyuán” 云团•家园 (Clouds.Home.)

Nuólā likāi zhàngfu yìhòu - Yēlinèikè xìjù ji 娜拉离开丈夫以后 - 耶利内克戏剧集 (What Happened after Nora Left her Husband - Collected plays of Jelinek), 2005

Contents: “Nuólā líkāi zhàngfu yùhòu, yòumíng ‘shèhuì zhīzhù”” 娜拉离开丈夫以后, 又名 “社会支柱” (What Happened after Nora Left her Husband or Pillars of Societies)

“Kèlālā S. (yīnyuè bēijù)” 克拉拉 S.（音乐悲剧）（Clara S. A Musical Tragedy) “Chéngbǎo jùyuàn (dài gē de xǐjù)" 城堡剧院（带歌的喜剧） (Burgtheater. Farce with singing)

“Bìngtài, yòumíng “xiàndài nŭxxìng' (xiàng yī chăng xì)”病态, 又名“现代女性” （向一场戏） (Illness or Modern Women. Like a Play)

“Bàngzi • gùnzi・gănzi (shǒugōng huá)” 棒子•棍子•杆子（手工华） (Rod, staff and crook. Handmade)

“Xiūxi zhàn, yòumíng ‘tāmen dōu zhème zuò’ (xỉjù)”休息站, 又名“他们都这么 做”（喜剧） (Services or They All Do It. A Comedy)

Sǐwáng yǔ shàonü 死亡与少女 (Death and the maiden), 2005

Contents: "Sǐwáng yǔ shàonŭ I (Báixuěgōngzhǔ)" 死亡与少女 I （白雪公主） (Death and the maiden I (Snow White))

“Šrwáng yǔ shàonŭ II (Shuìměirén)” 死亡与少女 II （睡美人） (Death and the maiden II (Sleeping Beauty))

“Sǐwáng yǔ shàonŭ III (Luōsuōméngdé)" 死亡与少女 III（罗莎蒙德） (Death and the maiden III (Rosamunde))

“Š̌wáng yǔ shàonŭ IV (Jiéjīi)” 死亡与少女 IV （杰基）（Death and the maiden IV (Jackie))

“Šrwáng yǔ shàonǔ V (qiáng)” 死亡与少女 V （墙） (Death and the maiden V (The wall))

Tuōtènăo shān 托特瑙山 (Totenauberg), 2005 
Jelinek has written 11 novels so far. The three novels bukolit.hörroman (bukolit. audio novel), Neid (Envy) and Die Kinder der Toten (The children of the dead) have not yet been published in the Chinese book market. Two of them have not been translated into any other language so far: bukolit, Jelinek's first, highly experimental work of prose of 1968, and Neid, her last novel to date which was published online on her personal website exclusively between 2007 and 2008. Die Kinder der Toten is widely acknowledged as Jelinek's most difficult or even 'unreadable' text (Mayer and Koberg 2007: 207). ${ }^{5}$ The translation of this novel into Chinese had been planned after the Běijīng October Literature \& Art Publishing House 北京十月文艺出版社 (Běijīng Shíyuè wényì chūbănshè) had bought the language rights in autumn 2004 (Sommerer 2009), but was never completed because of its level of difficulty, as the literary agent Cài Hóngjūn 蔡鸿君 revealed in an e-mail interview in 2010 (Cài 2010). Nevertheless, the extent to which Jelinek's prose work has been translated into Chinese can be regarded as remarkably comprehensive.

The number of 18 dramatic texts translated into Chinese might seem rather modest if measured against the wealth and significance of at least 40 works of this genre within Jelinek's oeuvre. However, 18 plays, in four out of 12 editions published in the course of the first year after the Prize, have to be considered an outstanding number. The status of the dramatic genre in the contemporary Chinese book market as described above certainly underlines this assessment. The two genres of drama and poetry make up merely 2 percent of the literature segment in the Chinese book market (Yáng 2006: 1-2).

These translations were the first by the Austrian writer ever published on the Chinese mainland. One of the translations, however, goes actually back to the 1990s and is connected with a major event that took place in Běijīng 北京 in September 1995, the United Nations Fourth World Conference on Women. The event had a significant impact on public and academic life in China and, as a result, 'women's research' 妇女研究 (fùnü yánjiū) and 'women's literature' 女性文学 (nüxing wénхиé) were booming (Zhang Jingyuan 2000: 162-163). In 1995, the largest number of books on women and by women in the history of the People's Republic of China was published (Zhang 2000: 177). The ubiquitous influence of the conference is also reflected in the launch of various large-scale translation projects, one of them initiated by the Institute of Foreign Literature of the Chinese Academy of Social Sciences (CASS) 中国社会科学院外国文学研究所 (Zhōngguó shèhui kēxuéyuàn wàiguó wénxué yánjiūsuǒ). Níng Yīng 宁瑛, by then researcher in German-language literature at the Institute, was in charge of the German section of the project, which

5 This reputation is also reflected in the fact that the unabridged text has so far been translated into only four languages (Russian, Polish, Dutch and French) (Elfriede Jelinek-Forschungszentrum 2011). Interesting insights into the difficulty of translating this novel into Dutch can be found in Arteel 1997 as well as Fuchs and Jelinek 1997. 
introduced influential and controversial foreign female writers to Chinese readers (Níng 2009). The very successful series included literary works by Japanese, Russian, English, German, Spanish, Italian, French and Arabic women writers and was published in several volumes. In this context, Níng Yīng and Zhèng Huáhàn 郑华汉, professor of German at Běijīng International Studies University 北京第二外国语学 院 (Běijīng dì'èr wàiguóyú xuéyuàn), chose to translate Elfriede Jelinek's most famous novel The Piano Teacher. The publishing house had even bought the copyright from the German publishing house Rowohlt, but finally decided not to publish the novel for several reasons (Chén and Lài 2004). In the first place, outside of a small circle of academic experts, Jelinek was an entirely unknown writer in China at that time. None of her works had been published up until then. Given the growing pressure caused by the transformations in the publishing industry, publishing a translation of an unknown, highly controversial writer, whose texts are notoriously difficult and sexually explicit, turned out to be a highly risky endeavour. The responsible editor of the publishing house, Hán Jìngqún 韩敬群, added in a newspaper interview in 2004 that the publishing house wanted to wait for the difficult market situation of that time to recover before publishing Jelinek's novel (Kāng and Gòu 2004). The translation was in fact not published until the Nobel Prize spectacularly stirred up the Chinese publishing industry in autumn 2004.

\section{The crucial role of intermediaries}

Intermediaries have been constantly neglected in historical studies and case studies of literary reception, which tend to be based on the traditional approaches of reception theories. Cultural goods, however, do not circulate on their own (Espagne 2006: 15). They are actively carried from one cultural context to another by distinct groups of intermediaries. The interactions between these groups finally constitute the cultural transfer. Intermediaries can be individuals or institutions in the political, economic or cultural field and may be based in the context of the country of origin as well as in the context of reception. In the case of Jelinek in China, the Chinese and German publishing houses, the translators and the literary agency, in particular, assumed a key role.

\section{The literary agency}

In autumn 2004, the literary agency HERCULES Business \& Culture Development $\mathrm{GmbH}$ was appointed by Jelinek's German publishers to mediate the trade of her language rights to China. The literary agency had been founded in 1998 by the noted translator and editor Cài Hóngjūn. It specialises in assisting publishers in the trade of 
copyrights between Germany and China (HERCULES Business \& Culture Development GmbH 2009). Its offices are located in Niederdorfelden in Germany, Nánjīng 南京 and Běijīng.

Regarding the translation and publication of Jelinek's works in Chinese, the role of the literary agency cannot be overestimated. A meticulous reconstruction of the course of events showed clearly that Cài Hóngjūn was more than a mediator in the trade of copyrights between the German and Chinese publishers. He and his agency were also significantly involved in the development of the publication strategy and in the selection processes regarding the Chinese publishers, the literary works and the translators.

When the Nobel Prize was announced in 2004, Elfriede Jelinek was literally unknown to the majority of Chinese publishers. These circumstances made the consultation of the literary agent even more essential, especially during the actual process of application for the copyrights. Immediately after the announcement, a variety of publishers had already shown great interest in publishing the Nobel laureate's works. However, they almost exclusively competed against each other for the most famous works, especially the novels, which had become the main subject of Chinese media coverage (Kāng and Gòu 2004). According to Cài's own account, which he published in 2006, he tried to urge the publishers to consider the laureate's dramatic texts as well (Cài 2006a: 46-47). As an expert and a renowned translator of Germanlanguage literature, he stressed that the inclusion of these texts was the only chance for Chinese readers to get in touch with a broad and appropriate spectrum of Jelinek's work. His efforts finally seemed to be successful. Four editions were dedicated to Jelinek's dramatic texts in addition to the eight editions of Jelinek's novels. This considerable outcome can certainly be traced back to the negotiations of the literary agent with the Chinese publishers.

The copyrights were finally bought by five different Chinese publishers, which is a rather exceptional procedure (Cài 2006a: 45-47). In most cases, the rights are not distributed to more than two publishers. This decision, however, reflects the publication strategy as developed by the German publishers together with the literary agency. The strategy was to introduce Jelinek's works on a broader scale and as soon as possible on to the market. It thus allowed participants to benefit from the publicity effect of the Nobel Prize as much as possible and also reduced the financial risk for each single publisher.

The literary agent was significantly involved in the selection of the publishing houses (Kāng and Gòu 2004, Cài 2005). Moreover, Cài Hóngjūn played a further important role in consulting the publishers on the selection of the translators too, as interviews with the translators confirmed (Shěn 2010, Yáng 2010).

The literary agent thus played a very powerful role in various ways. Because of the specific circumstances caused by the Nobel Prize and the Chinese publishing 
industry, Cài Hóngjūn and HERCULES clearly had a stake in the actual transfer of Jelinek's work to China.

\section{The publishers}

The German publishers of Elfriede Jelinek are the renowned publishing houses of Rowohlt, which has published the majority of her works, Berlin Verlag and Steidl Verlag. The Chinese translations were published by five publishing companies in total. Four of them are very prestigious Chinese publishing houses, which dominate the literature and translation market: Běijīng October Literature \& Art Publishing House 北京十月文艺出版社 (Běijīng Shíyuè wényì chübănshè), Shànghăi Translation Publishing House 上海译文出版社 (Shànghăi Yìwén chūbănshè), Chángjiāng Literature and Art Publishing House 长江文艺出版社 (Chángjiāng Wényì chūbănshè) and Yìlín Press 译林出版社 (Yilín chūbănshè).

The fifth publisher, in fact, represents a co-operation between a cultural agency, the Shànghăi Wànyǔ Culture and Art Co. Ltd. 上海万语文化艺术有限公司 (Shànghăi Wànyǔ wénhuà yìshù yŏuxiàn gōngsī), and the Publishing House of Shēnzhèn Press Group 深圳报业集团出版社 (Shēnzhèn Bàoyè Jítuán chūbănshè). This specific form of collaborative publishing reflects one of the most recent developments in the Chinese publishing industry. While the number of the 580 official, state-owned publishing houses registered in previous years has remained relatively stable, the number of highly influential private publishers has been growing rapidly (General Administration of Press and Publication 2011). Estimations vary between 5,000 (official estimation according to Buchinformationszentrum Peking 2009) and 10,000 (unofficial estimation according to Bartz 2009: 1). Private publishers are in fact not permitted to apply for publishing licenses or ISBNs. They mostly find themselves working on the margins of legal publishing in a kind of 'underground economy' and are often registered as cultural companies instead (Bartz 2009: 1). As a result, 'symbiotic relationships' evolve (Zhang Xiaoming 2006: 302). The stateowned publishers have started increasingly to work together with these private publishers, who are highly professional operators. In this process, the official publishers provide the ISBNs, which thus have become a tradable good (Zhang 2006: 302). In recent years, the private sector has gained in importance, especially in publishing foreign books in translation, and, consequently, in official acceptance. Publishing the works of a Nobel laureate in co-operation with a private publisher clearly confirms this trend. 


\section{The translators}

In cultural transfer processes which cross linguistic boundaries, translators play an indispensible role. Although they essentially shape the reception of literary works, their significance is often overlooked and their efforts underestimated. The following paragraphs are therefore dedicated to the Chinese translators of Jelinek's works, their backgrounds and working conditions, as well as the general situation of literary translators in China.

In China, as in many other countries, only very few publishers have their own 'in-house' translators. Most of them appoint translators on an ad hoc basis (Pugsley 2005: 390). Translators are therefore mainly occasional contractors, who are forced to make their living from other full-time employment. This precarious situation has led to a general shortage of dedicated literary translators in China (Pugsley 2005: 390), especially with regard to translations from the German language (Ding 1995: 145). Most of the translators are in fact academics, who translate literary works or technical documents, which are after all much more remunerative, in addition to their full-time research and teaching commitments. This phenomenon is certainly a global one and stems from the problematic status of the profession in general (Apel and Kopetzki 2003: 132-139). In China, however, the demand for translations grew rapidly and on an unprecedented scale in the past decades, due to political changes and economic reforms. Another factor is the relatively short history of reception of German-language and other foreign literature in China, which began on a larger scale only in the early 20th century (Zhang Yi 2007: 21-25). Scholars therefore cannot usually draw on an abundant record of already existing translations. They are in fact required to reconcile their research and teaching with the necessity of translating many literary works into Chinese for the first time (Zhang Yushu 2009: 495).

In sum, 28 translators were involved in translating Elfriede Jelinek's works into Chinese. This number is, again, rather remarkable, but is closely linked to the exceptional publishing conditions set off once more by the awarding of the Nobel Prize. Publishers wanted to release the works rewarded by the prize as soon as possible. The trend to appoint a considerable number of translators could also be observed in various European contexts after the Nobel Prize and already after the release of Michael Haneke's prize-winning film adaptation of The Piano Teacher in 2001 (Clar and Schenkermayr 2008: 42).

Unsurprisingly, every one of the 28 translators holds other employment and translates on a contract basis only (Wáng 2010, Mò 2009, Chén Liángméi 2009, Chén Mín 2010). The majority, 18 of them, were full-time academics, and several were working in the publishing industry themselves. Most of them had already translated a considerable number of literary and other works before. They were approached either by the literary agent or the publishing houses directly, especially those who had already worked with these publishers before. Apart from four transla- 
tors who were living in Germany and Austria by that time, most of the translators were based in the vicinity of the publishing houses. Some of the works were translated by a team of translators, which was also due to the fact that the allocated time to complete the translations was obviously rather short (between four weeks to several months, according to the interviewed translators, such as Mò (2009) and Chén (2010)). This is also one of the reasons why only one was involved in more than one translation, Yáng Liǔ 杨柳, who translated two dramatic texts, Das Schweigen (The silence) and Das Lebewohl (The farewell) (together with Zhāng Lì 张丽).

Given the precarious working conditions of the Chinese translators, their efforts were truly tremendous. Within only a few months, a comprehensive selection of the laureate's works was already made available in Chinese translation to an expectant Chinese public.

\section{Strategies of selling Jelinek in Chinese}

As explained above, translations of literary works in German face an enormous competition in the Chinese book market. Publishing houses obviously try even harder to attract as many readers as possible. One very effective means to catch the attention of shoppers in bookstores and online retailers is the layout of a book. An analysis of the book covers of the Chinese Jelinek editions reveals the publishers' marketing strategies.

Firstly, the subjects for illustration hardly refer to the subjects touched upon in the literary works. The cover designs apply a range of other motifs instead, such as female figures, of which several are presented in an explicitly sexualised way. The layouts of Lust (Lust), Greed (Gier) and Oh Wildnis, oh Schutz vor ihr (Oh wilderness, oh protection from it) represent especially conspicuous examples of this feature. In fact, the cover designs of all Jelinek editions published by the Chángjiāng Literature and Art Publishing House, just like these three novels, stand out with their eye-catching layouts in gaudy colours. Chángjiāng Publishing House is undoubtedly one of the strongest competitors in the Chinese market of literature and is, furthermore, well-known for its extraordinary success rate on national bestselling lists (Yáng 2006: 1). It had the largest share of Jelinek's works in Chinese and launched them in a series called Collected Works of Jelinek 耶利内克文集 (Yélinèikè wénjí). The strategy of choosing provocative layouts seems to have paid off well in the case of Chángjiāng Publishing House, as the number of print runs indicates. By extensively using insinuating portrayals of female figures on their covers, publishers are further trying to sell Jelinek's works under the guise of romantic or even erotic literature. This tendency can, interestingly, be found in the reception of Jelinek in other cultural contexts as well and is particularly evident with regard to the abovementioned novels (Clar and Schenkermayr 2008: 43). This could be linked to the 
provocative and intentionally misleading titles Jelinek chose for these novels, Lust, Greed and Oh Wildnis, oh Schutz vor ihr, as they seem to lend themselves to an erotic presentation.

The extensive use of references to the Nobel Prize and photos showing the Nobel laureate Elfriede Jelinek can be identified as another marketing strategy. It is again the Chángjiāng Publishing House which surpasses the other publishers with by far the greatest number of photos. Compared to the other publishers, which chose to print none (Publishing House of Shēnzhèn Press Group), one (Yìlín Press), two (Běijīng October Literature \& Art Publishing House) or three photos of Jelinek (Shànghăi Translation Publishing House), Chángjiāng Publishing House arranged for four different photos to be replicated on the covers and front pages as well as on every single verso page of their editions. This suggests that the Chinese publishers tried to make use of the prestige of the prize as well as of the effect of potential buyers recognising the picture they have been exposed to so intensively in the media after the laureate was announced. The private person Elfriede Jelinek, her biography and family background were widely discussed in the Chinese public discourse in autumn 2004 and thereafter (Lín 2005: 21). From the very beginning in the late 1960s, Jelinek's career as a writer has always been accompanied by extraordinary media attention to her private life (Bartens 1997: 37-38). Her novel The Piano Teacher, which has been almost exclusively interpreted in autobiographical terms, reinforced this media hype from the 1980s onwards.

Refering to Jelinek's reception in European countries, Clar and Schenkermayr showed that publishers usually refrained from the heavy use of erotic subjects and photos of the author in the more advanced stages of reception (Clar and Schenkermayr 2008: 53). The relatively simple layout of the re-published editions of Women as Lovers in 2008 and The Piano Teacher in 2010 suggests a similar development in China. The strategic approaches explained above therefore seem to be characteristics of reception processes at their very beginning.

\section{Jelinek in the Chinese book market: an unexpected success}

During the 'Jelinek fever' that struck China shortly after the announcement by the Swedish Academy, observers were already declaring that Jelinek would be among the most successful Nobel laureates in recent years (Qiū 2005: 88). Jelinek's works have indeed been extraordinarily well received in the Chinese book market, but this success was not evenly distributed among all the titles that have been published so far.

Between January and October 2005, 12 editions of Chinese translations of Jelinek's works were released on to the Chinese book market. The data as provided by the Chinese publishers show that the number of copies of the first print runs var- 
ied between 5,100 copies and 30,000 copies. The novels Lust and The Piano Teacher were the only editions printed more than once or twice. Lust was printed three times. The Piano Teacher was re-printed in seven runs. The performance of this novel clearly represents an exceptional case.

The reception of the other works, however, was not that successful. There are several reasons for this, ranging from Jelinek's thematic preferences and her demanding literary style to the distinctive traditional aesthetic values of the Chinese and the precarious conditions of translation. Another impact factor is to be found in the current situation of the Chinese publishing industry, which is increasingly exposed to the pressure of profit-making caused by the transformation to a market economy. The Nobel Prize's claim for outstanding literary and idealistic quality and the demands of the Chinese readership for entertainment are undoubtedly very divergent and hard to reconcile. The book has, furthermore, to stand up to the challenge imposed by other entertainment media. Literature has to compete with other very strong segments in the book market, while translations from German are marginalised by the dominant English and Asian languages in the translation market. The number of print runs and copies therefore mirrors the publishers' careful approach to publishing a controversial contemporary Austrian writer. They wanted to prevent potential financial loss. The data, however, also reflect the actual very limited success of literature like this in the retail market, even despite the promising label of the Nobel Prize. Distinctions can also be seen considering the specific genres. The fact that dramatic works play an extremely limited role in the literary market is evident, for example, in the decision of the Chángjiāng Publishing House to reduce the first print of its only compilation of dramatic works, Húnduàn Á'érbēisī shān 魂断阿尔卑斯山 (In the Alps), to 8,000 copies, whereas the editions for novels varied between 10,000 and even 20,000 copies.

Jelinek's novel The Piano Teacher, on the other hand, was a stunning success. In January 2005, Běijīng October Publishing House released 30,000 copies in the first print run and decided to re-print this edition at least twice in the same month. Between January and April, the novel was re-printed in seven runs of 110,000 copies altogether. This extraordinary print record indicates remarkable sales figures, which were further underlined by various bestselling lists of that time. The Piano Teacher was, for example, ranked in twelfth place in the OpenBook bestselling list of January 2005 (Yáng and Zhū 2007: 3). The print record also implies that this success was in fact rather unexpected. The publisher preferred to release a relatively small number of copies in each new print run. Given the difficult situation in the book market, a financial success from publishing German-language literature could not be expected at all. The Piano Teacher, however, became one of the most successful books of German-language literature in many years (Cài 2006b: 40).

Within Jelinek's oeuvre, The Piano Teacher is undoubtedly her most famous, best sold and most extensively studied novel. First published in 1983, it was widely 
acclaimed by the critics and launched the writer's international career (Mayer and Koberg 2007: 116-117). Scholars around the globe elaborated on this work by applying a wide range of approaches, such as feminism, Marxism, psychoanalysis, philosophy of language, theories of fascism, sexual pathology and many more. In 1988 Patricia Jünger adapted the novel to an opera; in 2001, Michael Haneke directed a prize-winning film version. Reasons for its success can, first of all, be found in the text itself. The novel touches thematically upon one of the most archaic relationships of human beings, the relationship between child and parents (Mayer and Koberg 2007: 117). A subject like this is easily accessible for readers in various cultural contexts. Furthermore, compared with later works of Jelinek, the plot of this novel is still easily recognisable and realistic, as are the characters and sexual constellations. At the same time the novel is still 'disturbing and perverse enough' to arouse the interest of the critics and the media (Chalmers 1997: 182).

For these reasons, The Piano Teacher was the first work by Jelinek to be introduced into many other cultural contexts (Bartens 1997: 44). The history of the international reception of this novel and its wide acclaim certainly had an impact on the Chinese reception too. Jelinek's reception in China cannot be seen as isolated but rather as closely entangled with an international network of reception. International testimonials on the covers of the Chinese editions are evidence of this, as well as, for example, the Chinese title itself, Gāngqín jiàoshī 钢琴教师 (literally the 'piano teacher'). This title clearly refers to the English title The Piano Teacher, as first translated by Joachim Neugröschel in 1988. The original title Die Klavierspielerin, however, literally means a female piano player instead of a piano teacher.

The Piano Teacher was, moreover, the first work of the Nobel laureate to be published in the Chinese book market, where it appeared as early as January 2005. It represented the first opportunity for an obviously expectant Chinese public to read the new laureate's works in Chinese. Other works were published in Chinese significantly later. The novel Michael. Ein Jugendbuch für die Infantilgesellschaft (Michael. A juvenile book for the infantile society), for instance, was released only in October 2005, already cutting across the announcement of the following year's new laureate. The outstanding success of The Piano Teacher has thus to be seen as well within the context of the annually recurring hype around the most recently announced Nobel laureate.

Overall, Elfriede Jelinek was one of the most successful Nobel laureates in China in the last decade. This is mainly due to the stunning success of the novel The Piano Teacher. Of course, translations of Nobel laureates in general tend to sell better than other translations (Yáng and Zhū 2007: 4). Even Nobel works, however, do not always become bestsellers. Between 1998 and 2003, for example, only one out of six Nobel laureates was ever ranked on a Chinese bestselling list (J. M. Coetzee's Disgrace in 2003) (Kāng and Gòu 2004). Jelinek's novel The Piano Teacher was already considered a bestseller during the Jelinek hype in January 2005. In 2006, 
Jelinek was still among the top ten bestselling Nobel laureates in the Chinese book market (fifth place, according to Yáng and Zhū 2007: 5). The number of titles released in Chinese translation further underlines Jelinek's extraordinary performance when compared with other Nobel laureates. Twelve titles by Elfriede Jelinek were published in China within only one year after the award. According to a study by OpenBook, the majority of Nobel laureates are represented by only one to ten titles each in China (Yáng and Zhū 2007: 2). Furthermore, it has to be noted that two editions have even been re-published since 2005. The fact that four of the twelve editions were dedicated to Jelinek's dramatic works is also remarkable. According to the same OpenBook analysis, the dramatic genre is acknowledged as a main reason for even Nobel laureates not being published at all (Yáng and Zhū 2007: 2). The authors further explain that, according to the available data, Asian writers, writers whose copyright has already expired, and writers who have already been published in China prior to the Nobel Prize, are the most successful Nobel laureates in China in the history of the prize (Yáng and Zhū 2007: 5). The fact that Jelinek did not fit into either of these categories underlines even more her exceptional success in the Chinese book market.

Elfriede Jelinek's works were re-published in 2008 and 2010. The Piano Teacher was re-published by the Běijīng October Publishing House in autumn 2010. Her novel Women as Lovers was included in the Phoenix Library 凤凰文库 (Fènghuáng wénkù), a project edited by the Phoenix Publishing and Media Group 凤凰出版传媒 集团 (Fènghuáng chūbăn chuánméi jítuán) in 2008. Yìlín Press, which published the novel for the first time in 2005, is part of this group. The Phoenix Library comprised seven series focusing on different subjects, such as political science, Marxism, philosophy, religious studies, Chinese studies, humanities and social sciences as well as foreign literature. The Phoenix Group announced the Phoenix Library project to highlight academic, ideological and theoretical achievements, in order to support China's progress as well as cultural exchange between China and the West (Phoenix Library Publishing Committee 2008: 1). Women as Lovers was included in the Series of modern and contemporary foreign literature 外国现当代文学系列 (Wàiguó xiàndāngdài wénxué xiliè). In this series, 21 volumes in translation were published in 2008, including the works of Nobel laureates and other foreign writers, such as Thomas Pynchon, Kurt Vonnegut, Joyce Carol Oates, Susan Sontag, Michael Cunningham, Iris Murdoch, Jean-Christoph Rufin, Carlos Fuentes, Kenzaburō Ōe and Winfried Georg Sebald.

It is, of course, still rather early and, in general, always difficult to predict the future fortune of literary works. The re-publishing of these novels of Jelinek, however, and the inclusion of Women as Lovers in this prestigious series in particular, suggest that Jelinek has already gained a notable status in China, even after the 'Jelinek fever' of the Nobel Prize has cooled down. 


\section{Concluding remarks}

This paper has been devoted to shedding light on the dynamics that facilitated the introduction and reception of the Austrian Nobel laureate Elfriede Jelinek in the People's Republic of China. It first outlined the current situation of the Chinese publishing industry, which is characterised by a process of reorganisation and financial restructuring. These transformations are increasingly forcing publishers to boost their sales' figures. At the same time, changing reader behaviour suggests that books are considered more and more as ordinary consumer goods, which have to satisfy readers' demands for entertainment. These transitions, as well as the competitive role for translated literature among other strong segments in the book market are particularly challenging for every new work entering the Chinese market.

The publicity effect of the world's best known literature prize, the Nobel Prize in Literature, clearly provided favourable conditions for the works of Elfriede Jelinek. As the data show, however, not even the works of a laureate are guaranteed a longer life cycle in the Chinese book market. Almost all of Jelinek's Chinese publishers have turned out to be among the most renowned and strongest players in the literary market. Facing the pressure of a free-market economy, they were nevertheless forced to apply various curious marketing strategies. The wide use of sexualised female figures suggests that they were trying to sell the Austrian writer's works under the guise of romantic or erotic literature. By extensively printing photos of Jelinek on and in their books, they apparently tried to exploit the publicity of the prize as effectively as possible. The selection of the works published as well as the statistics of print runs and copies further showed how profoundly the rapidly changing market is influencing the transfer of literature.

Given the challenging conditions of this Chinese book market, the extraordinary performance of Jelinek was truly unexpected. The Nobel Prize triggered off a remarkable reception in the Chinese book market as manifested in the number of editions, the proportion of dramatic texts and, especially, the success of the bestselling novel The Piano Teacher.

The paper has further showed that, although often overlooked by traditional approaches of reception and translation studies, intermediaries played a crucial role. The tremendous efforts made by the translators under precarious conditions often remain unseen, as much as the important and in fact very powerful task a literary agency assumes in the process of cultural transfer. The literary agency chosen here was in fact significantly involved in various ways, ranging from the publication strategy to the selection of the works, publishers and translators.

The future fate of Jelinek in Chinese remains vague, despite the very auspicious beginning. There is still a considerable potential that has not yet been fully exploited. Only 18 of the more than 40 dramatic texts of Jelinek's constantly growing oeuvre have been translated into Chinese. Until now, the dramatic texts of Elfriede 
Jelinek have not been put on stage in the People's Republic of China. These works, as well as a range of newly produced prose texts, are still waiting to be introduced to Chinese readers and, in further consequence, to Chinese theatregoers.

Regarding research on this interesting phenomenon of cultural transfer via literary translations and their reception in the foreign book market, there are certainly many aspects that would deserve closer attention. This paper has focused on Jelinek's works in the Chinese book market. The developments and tendencies in the Chinese academic discourse on Jelinek have to be elaborated in more detail on another occasion. In 2009, Herta Müller was awarded the Nobel Prize. A comparison between the reception of Müller's and Jelinek's works would also be of utmost interest. Furthermore, this paper could focus only on mainland China, but the collected data suggest that there is a vivid reception of Jelinek across the Taiwan Strait too. A closer examination of the Taiwanese translations and a comparison between these different contexts of the Chinese-speaking world will certainly be a worthwhile endeavour. 


\section{REFERENCES}

Apel, Friedmar, and Annette Kopetzki. Literarische Übersetzung. Stuttgart: J.B. Metzler, 2003

Arteel, Inge. "Die Rezeption Elfriede Jelineks in den Niederlanden und in Flandern." In Elfriede Jelinek. Die internationale Rezeption, edited by Daniela Bartens and Paul Pechmann. Graz: Droschl, 1997, pp. 136-159

Bartens, Daniela. "Vom Verschwinden des Textes in der Rezeption. Die internationale Rezeptionsgeschichte von Elfriede Jelineks Werk.” In Elfriede Jelinek. Die internationale Rezeption, edited by Daniela Bartens and Paul Pechmann. Graz: Droschl, 1997, pp. 28-51

Bartz, Jing. "A brief introduction to the Chinese publishing industry. Updated statistic, new trends and digitalization" (PDF file). Downloaded from Buchinformationszentrum Peking website, 2009, http://www.peking.buchinformationszentrum.org/de/news/01554/index.html, accessed February 2010

Buchinformationszentrum Peking. "Buchmarkt China. Grundlegende Informationen zum chinesischen Buchmarkt.” Buchinformationszentrum Peking website, 2009, http://www.peking.buchinformationszentrum.org/de/buchmarkt_china, accessed September 2009

Cài, Hóngjūn 蔡鸿君. “Fùlù: Yēlìnèikè zǒujìn Zhōngguó” 附录: 耶利内克走进中国 [Appendix: Jelinek enters China]. In Nuólā likāi zhàngfu yìhòu - Yélìnèikè xìjù jí 娜拉离开丈夫以后 - 耶 利内克戏剧集 [What Happened after Nora Left her Husband - Collected plays of Jelinek], Elfriede Jelinek, translated by Jiāo Yōngjiàn 焦庸鉴 et al., Shēnzhèn: Shēnzhèn Bàoyè Jítuán chūbănshè, 2005

Cài, Hóngjūn 蔡鸿君. “Yēlìnèikè rúhé láidào Zhōnggǔo (shàng)” 耶利内克如何来到中国 (上) [How Jelinek came to China, first part]. In Wàiguó wénxúe dòngtài 外国文学动态 [World literature recent developments], 1, 2006a, pp. 44-47

Cài, Hóngjūn 蔡鸿君. “Yēlìnèikè rúhé láidào Zhōnggǔo (xià)" 耶利内克如何来到中国 (下) [How Jelinek came to China, second part]. In Wàiguó wénxúe dòngtài 外国文学动态 [World literature recent developments], 2, 2006b, pp. 40-44

Cài, Hóngjūn 蔡鸿君 (literary agent). Email interview with author, January 2010

Chalmers, Martin. "In Zungen sprechen. Über die Mühen des Übersetzers, Elfriede Jelinek auf englisch gerecht zu warden.” In Elfriede Jelinek. Die internationale Rezeption, edited by Daniela Bartens and Paul Pechmann. Graz: Droschl, 1997, pp. 181-195

Chén, Liángméi 陈良梅 (Chinese translator of Jelinek). Email interview with author, November 2009

Chén, Mín 陈民 (Chinese translator of Jelinek). Email interview with author, January 2010

Chén, Yīmíng 陈一鸣, and Lài Wēi 赖薇. “Bèi cuòguò de Nuòbèiěr zuòpǐn” 被错过的诺贝尔作 品 [The missed Nobel work]. In Nánfāng zhōumò 南方周末 [Southern weekend], 14 October 2004, http://www.southcn.com/weekend/tempdir/200410150011.htm, accessed May 2009

China Publishing Today 出版商务周报 (Chūbăn shāngwù zhōubào). “China's Book Retail Market for the First Half of 2009." China Publishing Today website, 2009a, http://www.cptoday.com.cn/En/News/2009-09-10/240.html, accessed November 2009

China Publishing Today 出版商务周报 (Chūbăn shāngwù zhōubào). “Translated Books in the Chinese Retail Book Market.” China Publishing Today website, 2009b, http://www.cptoday.com.cn/En/News/2009-09-10/238.html, accessed November 2009

Clar, Peter, and Christian Schenkermayr. Theatrale Grenzgänge. Jelineks Theatertexte in Europa. Vienna: Praesens, 2008

Ding, Na. "Die Rezeption deutschsprachiger Literatur in der Volksrepublik China 1949-1990." Ph.D. diss., Ludwig-Maximilians-Universität zu München, 1995 
Elfriede Jelinek-Forschungszentrum. "Die weltweiten Übersetzungen von Elfriede Jelineks Werken samt Aufführungsdokumentation" (PDF file). Downloaded from Elfriede JelinekForschungszentrum website, 2011, http://www.elfriede-jelinekforschungszentrum.com/service/dokumentation, accessed May 2011

Espagne, Michel. "Jenseits der Komparatistik. Zur Methode der Erforschung von Kulturtransfers." In Europäische Kulturzeitschriften um 1900 als Medien transnationaler und transdisziplinärer Wahrnehmung. Bericht über das Zweite Kolloquium der Kommission "Europäische Jahrhundertwende - Literatur, Künste, Wissenschaften um 1900 in grenzüberschreitender Wahrnehmung”, edited by Ulrich Mölk. Göttingen: Vandenhoeck \& Ruprecht, 2006, pp. 13-32

Espagne, Michel, and Michael Werner. "Deutsch-französischer Kulturtransfer im 18. und 19. Jahrhundert. Zu einem neuen interdisziplinären Forschungsprogramm des C.N.R.S..” In Francia, 13, 1985, pp. 502-510

Fuchs, Gerhard, and Elfriede Jelinek. "Man steigt vorne hinein und hinten kommt man faschiert und in eine Wursthaut gefüllt wieder raus.' Ein E-Mail-Austausch.” In Elfriede Jelinek. Die internationale Rezeption, edited by Daniela Bartens and Paul Pechmann. Graz: Droschl, 1997, pp. 9-27

General Administration of Press and Publication (GAPP) 中华人民共和国新闻出版总署 (Zhōnghuá Rénmín Gònghéguó xīnwén chūbăn zǒngshǔ), http://www.gapp.gov.cn, accessed May 2011

HERCULES Business \& Culture Development GmbH, http://www.hercules-media.com, accessed October 2009

Jelinek, Elfriede. The Piano Teacher. Translated by Joachim Neugröschel. New York: Weidenfeld \& Nicholson, 1988

Jelinek, Elfriede. À, huāngyě 啊, 荒野 [Oh wilderness, oh protection from it]. Translated by Mò Guānghuá 莫光华. Wǔhàn: Chángjiāng Wényì chūbănshè, 2005

Jelinek, Elfriede. Gāngqín jiàoshī 钢琴教师 [The Piano Teacher]. Translated by Níng Yīng 宁瑛 and Zhèng Huáhàn 郑华汉. Běijīng: Běijīnng Shíyuè wényì chūbănshè, 2005; reprinted 2010

Jelinek, Elfriede. Húnduàn Ā'érbèisī shān 魂断阿尔卑斯山 [In the Alps]. Translated by Chén Jĩn 陈瑾 et al. Wǔhàn: Chángjiāng Wényì chūbănshè, 2005

Jelinek, Elfriede. Měihăo de měihăo de shíguāng 美好的美好的时光 [Wonderful, Wonderful Times]. Translated by Chén Mín 陈民 and Liú Hăiníng 刘海宁. Nánjīng: Yìlín chūbănshè, 2005

Jelinek, Elfriede. Mǐxià 'āi 'ér - Yì bù xiěgěi yòuzhì shèhuì de qīngnián dúwù 米夏埃尔 - 一部写 给幼稚社会的青年读物 [Michael. A juvenile book for the infantile society]. Translated by Yú Kuāngfù 余匡复. Shànghăi: Shànghăi Yìwén chūbănshè, 2005

Jelinek, Elfriede. Nuólā likkāi zhàngfu yìhòu - Yélìnèikè xìjù ji 娜拉离开丈夫以后 - 耶利内克戏 剧集 [What Happened after Nora Left her Husband - Collected plays of Jelinek]. Translated by Jiāo Yōngjiàn 焦庸鉴 et al. Shēnzhèn: Shēnzhèn Bàoyè Jítuán chūbănshè, 2005

Jelinek, Elfriede. Qíngyù 情欲 [Lust]. Translated by Xǔ Kuānhuá 许宽华 and Huáng Yùyún 黄玉 云. Wǔhàn: Chángjiāng Wényì chūbănshè, 2005

Jelinek, Elfriede. Š̌wáng yŭ shàonü 死亡与少女 [Death and the maiden]. Translated by Wèi Yùqīng 魏育青 and Wáng Bīnbīn 王滨滨. Shànghăi: Shànghăi Yìwén chūbănshè, 2005

Jelinek, Elfriede. Tānlán 贪婪 [Greed]. Translated by Dù Xīnhuá 杜新华 and Wú Yùkāng 吴裕康. Wǔhàn: Chángjiāng Wényì chūbănshè, 2005

Jelinek, Elfriede. Tuōtènăo shān 托特瑙山 [Totenauberg]. Translated by Shěn Xīliáng 沈锡良. Shēnzhèn: Shēnzhèn Bàoyè Jítuán chūbănshè, 2005

Jelinek, Elfriede. Wǒmen shì yòuniăo, băobèi 我们是诱鸟, 宝贝 [We are decoys, baby!]. Translated by Diāo Chéngjùn J承俊. Shēnzhèn: Shēnzhèn Bàoyè Jítuán chūbănshè, 2005 
Jelinek, Elfriede. Zhú ài de nürén 逐爱的女人 [Women as Lovers]. Translated by Chén Liángméi 陈良梅. Nánjīng: Yìlín chūbănshè 2005; reprinted 2008

Kāng, Kăi 康慨, and Gòu Yīnuó 勾伊娜. “Yēlìnèikè de Zhōngguó chūbǎn nántî” 耶利内克的中 国出版难题. In Zhōngguó xīnwén zhōukān 中国新闻周刊 [China news weekly], 45, 2004, http://www.xici.net/b374984/d24310660.htm, accessed November 2009

Keller, Thomas. "Kulturtransferforschung. Grenzgänge zwischen den Kulturen.” In Kultur. Theorien der Gegenwart, edited by Stephan Moebius and Dirk Quadflieg. Wiesbaden: VS Verlag für Sozialwissenschaften, 2011, pp. 106-119

Lín, Bái 林白. “Bù dú Yēlìnèikè de lǐyóu” 不读耶利内克的理由 [Reasons for not reading Jelinek]. In Nánfāng wéntán 南方文坛 [Southern cultural forum], 4, 2005, pp. 21-22

Mayer, Verena, and Roland Koberg. Elfriede Jelinek. Ein Porträt. Reinbek: Rowohlt, 2007

Mò, Guānghuá 莫光华 (Chinese translator of Jelinek). Email interview with author, November 2009

Níng, Yīng 宁瑛 (Chinese translator of Jelinek). Interview with author, Běijīng, September 2009

Nobelprize.org. "The Nobel Prize in Literature 2004." Nobelprize.org, 2004, http://nobelprize.org/nobel_prizes/literature/laureates/2004, accessed May 2011

Phoenix Library Publishing Committee 凤凰文库出版委员会 (Fènghuáng Wénkù Chūbăn Wěiyuánhuì). “Chūbăn shuōmíng” 出版说明 [Publishing explanation]. In Zhú ài de nürrén 逐爱的 女人 [Women as Lovers], Elfriede Jelinek, translated by Chén Liángméi 陈良梅. Nánjīng: Yìlín chūbănshè, 2008, pp. 1-2

Pugsley, Peter C. "Literary Text as Cross-cultural Exchange. The Selection of Australian Literature for the Chinese Book Market.” In Asian Studies Review, 29, 2005, pp. 383-393

Qiū, Huádòng 邱华栋. “Yēlìnèikè de xìng yǔ zhèngzhì" 耶利内克的性与政治 [Sex and politics in Jelinek]. In Nánfēngchuāng 南风窗 [Southwind window], 2/1, 2005, p. 88

Shěn, Xīliáng 沈锡良 (Chinese translator of Jelinek). Email interview with author, January 2010

Sommerer, Elisa (Rowohlt Foreign Rights Department). Email interview with author, November 2009

Sun, Jin, Yang Yang, and Mao Meng. "The Current Status of the Publishing Industry in China.” In Journal of Scholarly Publishing, 2009, pp. 92-102

Sun, Qingguo. "Economics of the Chinese Book Market." In Publishing Research Quarterly, 2002, pp. 54-63

Wáng, Bīnbīn 王滨滨 (Chinese translator of Jelinek). Email interview with author, January 2010

Yáng, Léi 杨雷. “2006 nián 1-6 yùe wénxúe túshū shìchăng fēnxî”” 2006 年 1-6 月文学图书市场 分析 [Analysis of the literary book market January to June 2006] (PDF file). Downloaded from OpenBook website, 2006, http://www.openbook.com.cn/searchresult_all.asp?filetype=\%BF\%AA\%BE\%ED\%D1\%D0\% BE\%BF\%B3\%C9\%B9\%FB, accessed November 2009

Yáng, Lì 杨丽 (Chinese translator of Jelinek). Interview with author, Vienna, January 2010

Yáng, Yì 杨毅, and Zhū Jiànhuà 朱健桦. “Cóng Kāijuàn shùjù kàn Nuòbèi’ěr wénxuéjiăng zuòjiā zuòpǐn zài Zhōngguó túshū língshòu shìchăng shàng de biăoxiàn” 从开卷数据看诺贝尔文学 奖作家作品在中国图书零售市场上的表现 [The performance of the works of Nobel literature laureates in the Chinese book retail market according to the data of OpenBook] (PDF file). Downloaded from OpenBook website, 2007, http://www.openbook.com.cn/searchresult_all.asp?filetype=\%BF\%AA\%BE\%ED\%D1\%D0\% BE\%BF\%B3\%C9\%B9\%FB, accessed November 2009 
Zhang, Jingyuan. “Breaking Open. Chinese Women's Writing in the Late 1980s and 1990s." In Chinese Literature in the Second Half of a Modern Century. A Critical Survey, edited by Pangyuan Chi and David Der-wei Wang. Bloomington: Indiana University Press, 2000, pp. 161179

Zhang, Xiaoming. "From Institution to Industry. Reforms in Cultural Institutions in China." Translated by Bao Jiannu. In International Journal of Cultural Studies, 9/3, 2006, pp. 297-306

Zhang, Yi. Rezeptionsgeschichte der deutschsprachigen Literatur in China von den Anfängen bis zur Gegenwart. Frankfurt am Main: Peter Lang, 2007

Zhang, Yushu. "Die Wichtigkeit der Übersetzung bei der Rezeption der deutschen Literatur in China.” In Mein Weg zur Literaturstraße. Ausgewählte Arbeiten eines chinesischen Germanisten, Zhang Yushu. Würzburg: Königshausen \& Neumann, 2009, pp. 485-496 


\section{GLOSSARY}

À, huāngyě

Bàngzi • gùnzi • gănzi

(shǒugōng huá)

Běijīng dì'èr wàiguóyǔ

xuéyuàn

Běijīng Kāijuàn xìnxī jìshù

yǒuxiàn gōngsī

Běijīng Shíyuè wényì chūbăn-

shè

Bìngtài, yòumíng 'xiàndài

nüxxing' (xiàng yī chăng xì)

Chángjiāng Wényì chūbănshè

Chéngbăo jùyuàn (dài gē de xìui)

\section{Chénmò}

Fènghuáng wénkù

Fènghuáng chūbăn chuánméi

jítuán

Gāngqín jiàoshī

fùnü yánjīū

Húnduàn Ā'èrbēisī shān

huiběn mànhuà

Kèlālā S. (yīnyuè bēijù)

\section{Mànyóuzhě \\ măyáng \\ Měihăo de měihăo de shíguāng \\ Mǐxià 'āi 'ěr - Yī bù xiěgěi yòuzhì shèhuì de qingnián dúwù}

Nuólā likkāi zhàngfu yǐhòu, yòuming 'shèhuì zhīzhù'
啊, 荒野

棒子・棍子・杆子（手工 华)

北京第二外国语学院

北京开卷信息技术有限公 司

北京十月文艺出版社

病态, 又名 “现代女性” （向一场戏）

长江文艺出版社

城堡剧院（带歌的喜剧）

沉默

凤凰文库

凤凰出版传媒集团

钢琴教师

妇女研究

魂断阿尔卑斯山

绘本漫画

克拉拉 S. (音乐悲剧)

漫游者

码洋

美好的美好的时光

米夏埃尔 - 一部写给幼 稚社会的青年读物

娜拉离开丈夫以后, 又名 “社会支柱”
Oh wilderness, oh protection from it (Oh Wildnis, oh Schutz vor ihr)

Rod, staff and crook. Handmade (Stecken, Stab und Stangl. Eine Handarbeit)

Běijīng International Studies University Běijīng OpenBook IT Co. Ltd.

Běijīnng October Literature \& Art Publishing House Illness or Modern Women. Like a Play (Krankheit oder Moderne Frauen. Wie ein Stück)

Chángjiāng Literature and Art Publishing House Burgtheater. Farce with singing (Burgtheater. Posse mit Gesang)

The silence (Das Schweigen)

Phoenix Library

Phoenix Publishing and Media

Group

The Piano Teacher (Die Klavierspielerin)

women's research

In the Alps (In den Alpen)

illustrated books and cartoons

Clara S. A Musical Tragedy

(Clara S. Musikalische

Tragödie)

The wanderer (Der Wanderer) the total price of books Wonderful, Wonderful Times

(Die Ausgesperrten)

Michael. A juvenile book for the infantile society (Michael. Ein Jugendbuch für die Infantilgesellschaft)

What Happened after Nora Left her Husband or Pillars of Societies (Was geschah, nachdem Nora ihren Mann verlassen hatte oder Stützen der Gesellschaften) 
Nǘmówáng

nüxxing wénxué

qīngchūn wénxué

Qíngyù

săn záwén

Shànghăi Wànyǔ wénhuà yìshù yǒuxiàn gōngsī

Shànghăi Yìwén chūbănshè

Shēnzhèn Bàoyè Jítuán chūbănshè

Sǐwáng yǔ shàonü I (Báixuěgōngzhǔ)

Sǐwáng yǔ shàonü II

(Shuìméirén)

Sǐwáng yǔ shàonü III (Lū̄suōméngdé)

Sǐwáng yǔ shàonü IV (Jiéjī)

Š̌wáng yǔ shàonü V (qiáng)

Tānlán

Tuōtènăo shān

Wàiguó xiàndāngdài wénxué

xìliè

wénxué lìlùn yǔ yánjiū

wénxué qitā

Wǒmen shì yòuniǎo, băobèi!

xiăoshuō

xìjù shīgē

Yēlìnèikè wénjí

Yìlín chūbănshè

Yúntuán • jiāyuán

Zàijiàn

Zhōngguó gǔdiăn wénxué

Zhōnghuá Rénmín Gònghéguó xīnwén chūbăn zǒngshŭ

Xiūxi zhàn, yòumíng 'tāmen dōu zhème zuò' (xĭjù)
女魔王

女性文学

青春文学

情欲

散杂文

上海万语文化艺术有限公 司

上海译文出版社

深圳报业集团出版社

死亡与少女 I （白雪公 主)

死亡与少女 II（睡美人）

死亡与少女 III （罗莎 蒙德）

死亡与少女 IV （杰基）

死亡与少女 $\mathrm{V}$ （墙）

贪婪

托特瑙山

外国现当代文学系列

文学理论与研究

文学其他

我们是诱鸟, 宝贝

小说

戏剧诗歌

耶利内克文集

译林出版社

云团・家园

再见

中国古典文学

中华人民共和国新闻出版 总署

休息站, 又名 “他们都这

么做”（喜剧）
The erlqueen (Die Erlkönigin)

women's literature

children's literature

Lust (Lust)

essay

Shànghăi Wànyǔ Culture and

Art Co. Ltd.

Shànghăi Translation Publishing

House

Publishing House of Shēnzhèn

Press Group

Death and the maiden I (Snow

White) (Der Tod und das Mäd-

chen I (Schneewittchen))

Death and the maiden II (Sleep-

ing Beauty) (Der Tod und das

Mädchen II (Dornröschen))

Death and the maiden III (Rosamunde) (Der Tod und das

Mädchen III (Rosamunde))

Death and the maiden IV (Ja-

ckie) (Der Tod und das Mäd-

chen IV (Jackie))

Death and the maiden $V$ (The wall) (Der Tod und das Mäd-

chen V(Die Wand))

Greed (Gier)

Totenauberg (Totenauberg)

Series of modern and contemporary foreign literature

literary theory and research

other literature

We are decoys, baby! (wir sind

lockvögel, baby!)

novel

drama and poetry

Collected Works of Jelinek

Yìlín Press

Clouds.Home. (Wolken.Heim.)

The farewell (Das Lebewohl)

classical Chinese literature

General Administration of Press

and Publication (GAPP)

Services or They All Do It. A

Comedy (Raststätte oder Sie

machens alle. Eine Komödie) 
Zhōngguó shèhuì kēxuéyuàn wàiguó wénxué yánjiūsuǒ

Zhú ài de nürén
中国社会科学院外国文学 研究所

逐爱的女人
Institute of Foreign Literature of the Chinese Academy of Social Sciences (CASS)

Women as Lovers (Die Liebhaberinnen) 